\begin{abstract}
Iranica
Abstracta Iranica Revue bibliographique pour le domaine irano-aryen

Volume 32-33 | 2013

Comptes rendus des publications de 2009-2010

\section{R. Boucharlat. The 'paradise' of Cyrus at Pasargadae, the core of the Royal ostentation}

\title{
Rédaction
}

\section{(2) OpenEdition \\ 1 Journals}

\section{Édition électronique}

URL : http://journals.openedition.org/abstractairanica/40207

DOI : 10.4000/abstractairanica. 40207

ISSN : 1961-960X

Éditeur:

CNRS (UMR 7528 Mondes iraniens et indiens), Éditions de l'IFRI

\section{Édition imprimée}

Date de publication : 1 décembre 2013

ISSN : 0240-8910

\section{Référence électronique}

Rédaction, "R. Boucharlat. The 'paradise' of Cyrus at Pasargadae, the core of the Royal ostentation ", Abstracta Iranica [En ligne], Volume 32-33 | 2013, document 39, mis en ligne le 01 juillet 2016, consulté le 02 octobre 2020. URL : http://journals.openedition.org/abstractairanica/40207 ; DOI : https:// doi.org/10.4000/abstractairanica.40207

Ce document a été généré automatiquement le 2 octobre 2020.

Tous droits réservés 


\title{
R. Boucharlat. The 'paradise' of Cyrus at Pasargadae, the core of the Royal ostentation
}

\author{
Rédaction
}

\section{RÉFÉRENCE}

R. Boucharlat. « The 'paradise' of Cyrus at Pasargadae, the core of the Royal ostentation ", in : J. Ganzert, J. Wolsche-Bulmahn, Hg., Bau- und Gartenkultur zwischen Orient" und Okzident"-Interdependenzen. Fragen zu Herkunft, Identität und Legitimation. Martin Meidenbauer Verlag, p. 47-64. (Beiträge zur Architektur- und Kulturgeschichte Leibnitz Universität Hannover, Bd. 3)

1 Le faible nombre de constructions sur le site de Pasargades et leur répartition très lâche conduisent l'A. à envisager la majeure partie du site comme un vaste parc, dans laquelle sont disposés quelques bâtiments de prestige. L'ensemble donnerait une idée de ce qu'était un 'paradis', le paradeisos création perse, que les auteurs grecs ont admiré en d'autres lieux d'Anatolie ou du Levant. De plus, la vallée proche du tombeau de Cyrus pourrait elle aussi avoir été aménagée et surtout irriguée par décision royale, faisant de ce lieu un autre type de paradis (réserve de chasse, jardin, exploitation agricole...). 


\section{AUTEURS}

\section{RÉDACTION}

Directeur de la revue et secrétariat (Paris) 